\title{
Career As an Internal Auditor: Analysis on Determinant Factors of Accounting Students' Choice Toward This Career Path
}

\author{
Siti Maria WARDAYATI ${ }^{1}$, Nining Ika WAHYUNI ${ }^{2}$, Alfi ARIF ${ }^{3}$ \\ 1,2,3 Faculty of Economics and Business, Jember University, East Java, Indonesia \\ Email: siti.maria@unej.ac.id ${ }^{1}$, nining.feb@unej.ac.id², alfi.rif@unej.ac.id ${ }^{3}$ \\ ${ }^{*}$ Corresponding Author
}

\author{
Received: 20.09.2021 Accepted: 12.11.2021 Published: 02.12.2021 DOI: 10.47750/QAS/22.185.21
}

\begin{abstract}
This research was conducted to identify the determinants of career choice as internal auditors by accounting students. Determinants consisting of financial rewards, professional training, social values, work environment, labor market considerations and personality have been used to build the model. Respondents consisted of 105 accounting students at the University of Jember Indonesia who had attended IIA Academic Awareness Program. The research data collection technique uses primary data by distributing questionnaires. The model was tested by multiple linear regression analysis. The results showed that the factors of professional training and personality are the main determinants of student career choices as internal auditors compared to other determinants. Therefore, we suggest that both factors should always be improved through education.
\end{abstract}

Keywords: Financial Rewards, Professional Training, Social Values, Work Environment, Job Market Considerations, Personality, Career Selection

\section{Introduction}

Accounting students will be able to pursue careers in several types of professions in the accounting field. Apart from being an accountant, they can have a career as an auditor. Career choices require consideration of the benefits that will be realized in the future, such as the ability to access desired positions, earn a living, gain independence, and develop one's competence (Walker, 2016). Because a planful attitude necessitates a focus on the future and career choices can be viewed of as maturity or preparedness to sign, one could argue that those who are future-oriented are more successful (Super, 1980). The choice of the right profession, which determines the type of life process in the future, is a critical issue for both people and society. There are many things to consider when choosing a career path.

The Institute of Internal Auditors (The IIA) recently named the Accounting Program of Economics and Business Faculty at the University of Jember (Unej) as one of the IIA's Internal Audit Awareness Program Schools. The Internal Audit Academic Awareness Program was established to honor the university's commitment and efforts to educate students with the information and expertise they need to pursue a career in internal audit. Some of the benefits of the program for participating universities are as follows: employers check the list of IIA schools that offer internal audit when deciding what level of internal audit education their new employees should have; upon request, guest lecturers can be provided; universities participating in the program gain access to a wide range of educational materials; in addition there are more opportunities to share ideas and materials with other educators who teach internal audit. Thus, it can be said that this study program has equipped its students with adequate skills if they want a career as internal auditors.

The role of internal auditors is needed by the organization in maintaining the sustainability of the organization (lin, abbort). However, the trend of interest in a career as an internal auditor indicates that companies still face significant difficulties in recruiting and employing highly qualified personnel to perform internal audit work. Several reports published by Ernst \& Young, 2007; Institute of Internal Audit (2011); Pricewaterhouse Coopers (2006) shows that the profession as an internal auditor is less attractive to accounting graduates. Murphy (2013) predicts that in 2018 large companies will experience a shortfall of talented internal auditors of up to $30 \%$. Various stereotypes or myths about work as a internal auditors, such as work as an internal auditor is boring, internal auditors work as fault-finders, internal auditors are not liked by other parts, auditors internal as "corporate police" and the internal auditing department is filled with "outcasts" from other departments (Burton et al., 2014; Chambers, 2012; Navallas, del Campo, \& Camacho-Miñano, 2017 ), is a challenge to get the best talent to fill the position as internal auditor.

There are considerable challenges in trying to find suitable and talented internal auditors with various stereotypes and negative perceptions attached to this profession, it is important to know the factors that can influence the interest of accounting students to choose the profession as internal auditors in their career paths. Previous research on the factors that determine student interest in choosing a future career has been widely carried out (Afaq Ahmed et al., 2017). These factors include the work environment, professional recognition, professional 
training, social values, financial rewards and labor market considerations which are proven to have a significant influence on the career choices of accounting students as public accountants (Pekkaya, 2015)(Timporok et al., 2019)(Nouri et al., 2005)(Dippa et al., 2020). However, the career in question is more focused on the profession as a public accountant. Research that explores the determinants of interest in a career as an internal auditor is still rarely done. Therefore, this study aims to re-examine these factors on student interest in a career as an internal auditor. The respondents of this study were accounting students who took part in the Academic Awareness Program (AAP) held by The Institute of Internal Auditors Indonesia (IIA) at the University of Jember.

\section{Literature Review and Hypotheses
Development}

This study uses the expectancy theory which is part of the motivation theory as the basic concept of choosing a career or profession. This theory states that the intensity of the tendency to perform in a certain way depends on the intensity of the expectation that performance will be followed by definite results and on the attractiveness of the results to the individual (Vroom, 1964). In more practical terms, expectancy theory says that employees will put in more effort and harder if they believe that effort will result in good performance appraisals. Good performance appraisal will encourage organizational rewards such as bonuses, increases in financial rewards/salaries and promotions. If the reward is obtained, it can meet the employee's personal goals. Expectancy theory focuses on three relationships:

1. Effort-performance relationship: Probability calculated by those who put in a specific amount of effort to achieve a certain level of performance.

2. Relationship between performance and reward: To what extent does the individual believe that working at a given level will inspire them to achieve the desired results.

3. Personal reward-goal relationship: the amount to which organizational awards suit the aims or demands of an individual's personality, as well as the individual's potential attractiveness to these rewards.

The key to this expectancy theory is understanding individual goals and the relationship between effort and past performance between performance and reward. The career choice of an accounting student is determined by the expectations of the career they will choose after they graduate, with consideration of whether the career is considered to be able to meet their individual needs and whether the career has its own charm for them. Students have expectations about the career they choose whether the career can fulfill what they want. This study examines several research variables, namely financial rewards and professional training to test the Effort-performance relationship, the work environment and labor market considerations to test the Performance-reward relationship, as well as social values and personality to test the Personal reward-goal relationship. The following is an explanation of each variables:

\section{a) Financial rewards}

Financial rewards or income are believed to be fundamentally for most companies as the main attraction to provide satisfaction to their employees because income is obtained as a contra-achievement from the work that has been done (Timporok et al., 2019). Until now, financial rewards are still seen as a measuring tool to assess the consideration of services that have been provided by employees as rewards that have been obtained. Messier et al. (2011) revealed that the placement of the internal audit function as Management Training Ground (MTG) reduces the trust (reliance) of the external auditor which results in an increase in audit fees. Financial rewards or income are believed to be fundamentally for most companies as the main attraction to provide satisfaction to their employees because income is obtained as a contra-achievement from the work that has been done (Ahmed et al., 1996; Filipzak, 1997; Butler et al., 2000)). Kerka (2000) says that the amount of information people use and the financial resources they have at their disposal have a substantial impact on how they choose a vocation.

\section{b) Professional Training}

Professional training includes matters relating to recognition of achievement, training program is an educational program that is carried out in a systematic and organized manner and is guided by professionals to improve abilities in the field of work in order to achieve the work goals desired by the company or organization. and improve and develop the attitudes, behavior, skills and knowledge of employees in accordance with the wishes of the company (Dippa et al., 2020). Chambers (2012) some myths about the profession of internal auditors. One of them is that internal auditors are accountants with training, which means that this profession is focused on the company's financial records and the potential for misstatements or fraud that occur within the company. With the increasing number of professional training followed by an internal auditor, this is expected to change this perception and increase public confidence in its other capabilities.

\section{c) Social Values}

Social values are related to people's views of the social values of a chosen career, care and attention from around by an accountant will increase the intrinsic value and selling value of accountants (Dippa et al., 2020). Burton et al. (2014) stated that various perceptions, stereotypes and myths about internal auditors can prevent individuals from applying for jobs as internal auditors, especially when the role of internal auditors focuses more on the assurance role than the consulting role. The phenomenon that has developed recently is shown in various studies such as Messier et al. (2011) and Bartlett, Kremin, Saunders, \& Wood (2017) indicate that the role of internal audit is more of a consultant. Burton et al. (2014) argues that this role change will be able to reduce negative perceptions of the internal audit profession.

\section{d) Work environment}

Daulay (2016) says that the work environment is everything that is around the workers and can affect themselves in carrying out the tasks assigned, the work environment is an atmosphere that includes the nature of work, the level of competition between employees and work pressure are factors of the work environment. Accounting students who have a high competence spirit usually tend to choose a work environment that can provide challenges so that students will get their own satisfaction when they can complete the challenges given well. The survey results from Wood \& Wilson (1989) found evidence that the work of internal auditors is considered by people outside the internal audit field as mistake finders, bean counters, nitpickers, unnecessary evil, auditor weenies, outsiders, dirt diggers, company sneaks, hit men. , and storm troopers. Then, like the perception that is also developing in Indonesia. Cooper (2008) stated that one of the internal audit executives of a large company once said that the internal audit department is like an elephant tomb, people who do not fit in any part of the company or are close to after his retirement, he 


\section{GENERAL MANAGEMENT}

will be placed in the internal audit department.

\section{e) Labor Market Considerations}

Labor market considerations are closely related to the jobs that will be accessible in the future. Jobs with a wider job market will be more desirable than jobs with a smaller labor market. This is because the opportunities for development from work and the rewards will be more. Consideration of the labor market can be a reason or factor for someone in determining his career (Lestari (2016) said that labor market considerations include, opportunity to develop, ease of getting a job, job security are factors where the chosen career can last for a long time. Career prospects are expected to influence the interest of potential applicants for this position. Burton et al. (2014) divide these career prospects into two categories, being promoted as part of the company's management at a higher level or occupying a position as a leader in the internal audit function itself. The prospect of career development is also suspected as one of the factors that influence applicants' desire to occupy positions as members of the internal audit department.

\section{f) Personality}

Personality is one of the potential determinants of individual behavior when dealing with certain situations/conditions (Lestari, 2011). This proves that personality influences a person's behavior. Personality shows how to control or reflect one's personality at work. Personality is a psychological characteristic from within that determines and reflects how a person responds to his environment. An auditor must not only have expertise, but must be balanced with Professional Skepticism (Professional Skepticism). Vocational theory (Holland, 1959; Holland \& Gottfredson, 1992) implies that when considering career potential, individuals will tend to seek positions that they perceive as having a fit between their personality and the profession.

Thus, the factors mentioned above are thought to influence the interest of accounting students to choose internal auditors as their future careers. This prediction stated in the following hypothesis:

H1 : Financial Rewards has an effect on Career Selection as Internal Auditor

$\mathrm{H} 2$ : Professional Training has an effect on Career Selection as Internal Auditor

H3 : Social Values has an Effects on Career Selection as Internal Auditor

$\mathrm{H} 4$ : Work Environment has an effect on Career Selection as Internal Auditor

H5 : Labor Market Considerations has an effect on Career Selection as Internal Auditor

$\mathrm{H} 6$ : Personality has an Effect on Career Selection as Internal Auditor

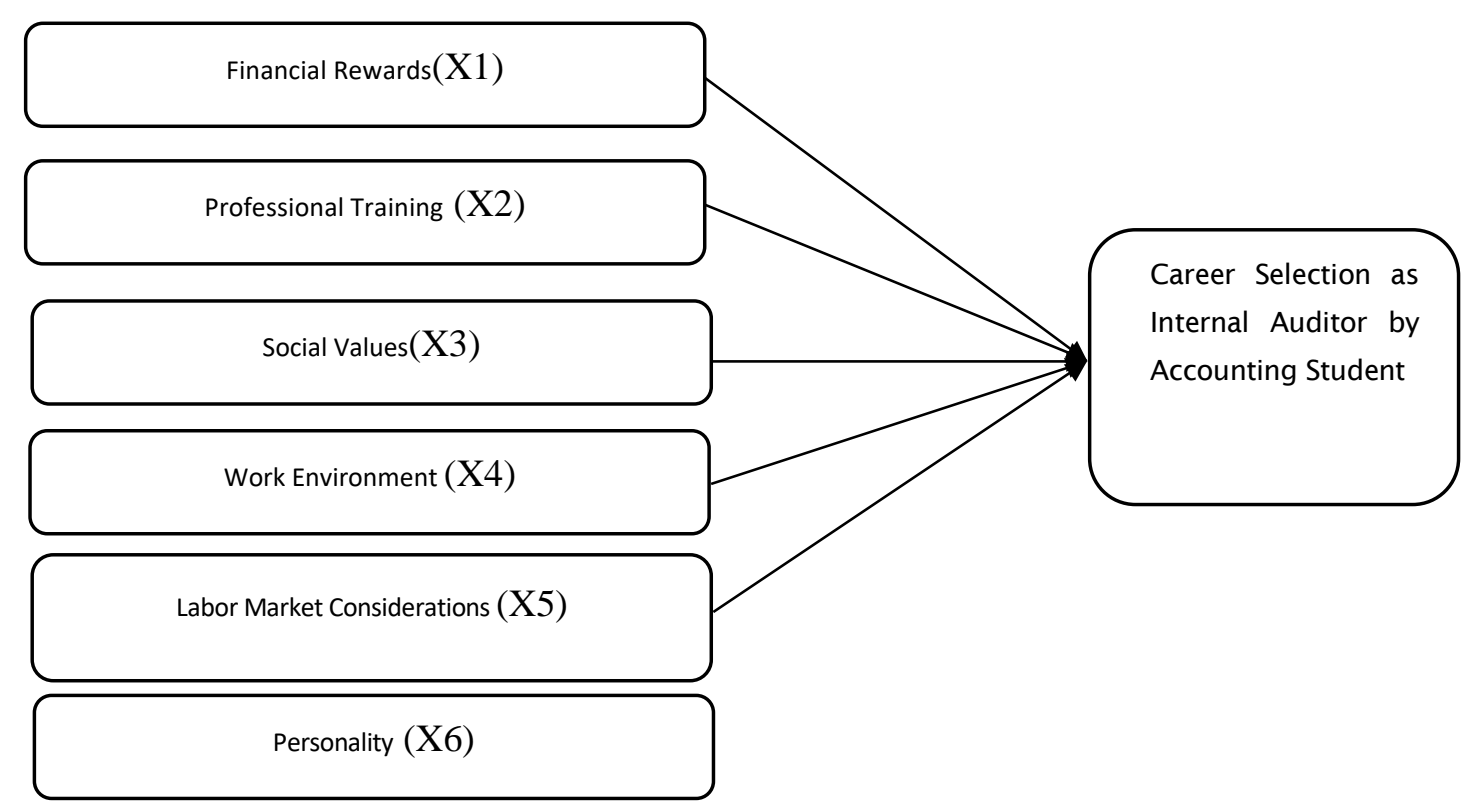

Figure 1: Problems Framework

\section{Research methodology}

This type of research is a quantitative research with a survey method. Questionnaires were distributed to 105 accounting students participating in the Academic Awareness Program (AAP) at the University of Jember. The data collection used in this study was a five-point Likert-scale questionnaire with answers from strongly disagree to strongly agree. This scale is used to measure the subject's response on a 5-point scale with equal intervals (Sekaran 2017:19). An explanation of the research variables and their measurements is set out in table 1 below. 


\section{GENERAL MANAGEMENT}

\begin{tabular}{|c|c|c|c|}
\hline Variables & Concept of Variables & Indicators & $\begin{array}{l}\text { Questionnaires } \\
\text { (Numbers) }\end{array}$ \\
\hline \multirow[t]{5}{*}{$\begin{array}{l}\text { Career Selection as } \\
\text { Internal Auditor (Y) }\end{array}$} & \multirow{5}{*}{$\begin{array}{l}\text { Accounting Students of } \\
\text { Jember University having } \\
\text { the interest on becoming } \\
\text { Internal Auditor after } \\
\text { finishing the study. }\end{array}$} & $\begin{array}{l}\text { The desire to become a } \\
\text { competent Internal Auditor }\end{array}$ & 1 \\
\hline & & $\begin{array}{l}\text { Having an ambition to be an } \\
\text { Internal Auditor }\end{array}$ & 2 \\
\hline & & $\begin{array}{l}\text { Digging lots of knowledge related } \\
\text { to Internal Auditor profession }\end{array}$ & 3 \\
\hline & & $\begin{array}{l}\text { Seeking information related to } \\
\text { Internal Auditor }\end{array}$ & 4 \\
\hline & & $\begin{array}{l}\text { Having the courage to understand } \\
\text { the profession of internal Auditor }\end{array}$ & 5 \\
\hline \multirow{3}{*}{$\begin{array}{l}\text { Financial Rewards } \\
\text { (X1) }\end{array}$} & \multirow{3}{*}{$\begin{array}{l}\text { The results obtained as a } \\
\text { counter-achievement from } \\
\text { work that is believed to be } \\
\text { the main attraction to } \\
\text { provide satisfaction to } \\
\text { employees (Lestari, 2016) }\end{array}$} & High starting salary & 1 \\
\hline & & Faster salary increase & 2 \\
\hline & & The availability of retired fund & 3 \\
\hline \multirow[t]{4}{*}{$\begin{array}{l}\text { Professional training } \\
\text { (X2) }\end{array}$} & \multirow{4}{*}{ 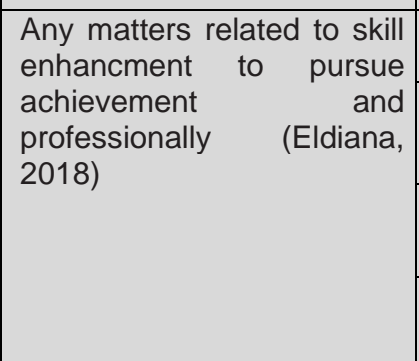 } & Job training before starting work & 4 \\
\hline & & $\begin{array}{l}\text { Attending trainings held by other } \\
\text { institutions }\end{array}$ & 5 \\
\hline & & $\begin{array}{l}\text { Attending regular training held by } \\
\text { the internal institutions }\end{array}$ & 6 \\
\hline & & $\begin{array}{l}\text { Obtaining a variety of work } \\
\text { experience }\end{array}$ & 7 \\
\hline \multirow[t]{4}{*}{$\begin{array}{l}\text { Social Value } \\
\text { (X3) }\end{array}$} & \multirow{4}{*}{$\begin{array}{l}\text { The value of a person which } \\
\text { is seen from other people's } \\
\text { point of view within the work } \\
\text { environment (Daulay, 2016) }\end{array}$} & $\begin{array}{l}\text { To provide opportunities for } \\
\text { social activities }\end{array}$ & 8 \\
\hline & & $\begin{array}{l}\text { To provide opportunities to } \\
\text { interact with other people }\end{array}$ & 9 \\
\hline & & The need of time for hobbies & 10 \\
\hline & & Examining individual behavior & 11 \\
\hline \multirow{4}{*}{$\begin{array}{l}\text { Work Environmer } \\
\text { (X4) }\end{array}$} & \multirow{4}{*}{$\begin{array}{l}\text { Related to the nature of } \\
\text { work, level of competition } \\
\text { and the amount of work } \\
\text { pressure (Daulay, 2016) }\end{array}$} & Routine work & 12 \\
\hline & & Work can be completed faster & 13 \\
\hline & & More attractive work & 14 \\
\hline & & Work Environment atmosphere & 15 \\
\hline \multirow[t]{2}{*}{$\begin{array}{lr}\text { Labor } & \text { market } \\
\text { considerations }(X 5)\end{array}$} & \multirow{2}{*}{$\begin{array}{l}\text { (Yanti, 2014) factors making } \\
\text { careers searchable and } \\
\text { long-lasting }\end{array}$} & High work safety & 19 \\
\hline & & the job offered is accessible & 20 \\
\hline $\begin{array}{l}\text { Personality } \\
\text { (X6) }\end{array}$ & $\begin{array}{l}\text { Potential determinants of } \\
\text { individual behavior in } \\
\text { dealing with certain situation } \\
\text { and condition (Yanti, 2014) }\end{array}$ & Appropriate personality & 21 \\
\hline
\end{tabular}

Table 1: Variables Measurement 


\section{GENERAL MANAGEMENT}

At the data analysis stage, we used several tests to ensure that the data we obtained were valid and reliable. The validity test in this study is by doing a bivariate correlation between each indicator score and the total construct score. The construct is said to be valid if the Pearson Correlation value is $>0.5$ and significant is $<0.05$. The function of the reliability test is as a tool to measure the questionnaire which is an indicator of the variable. A questionnaire is said to be reliable if the respondent's answer to the statement is consistent from time to time (Sugiyono, 2017:121). This study uses the Cronbach's Alpha testing technique. The test criteria is if Cronbach's Alpha $(\alpha)>0.6(60 \%)$ then the instrument used can be said to be reliable (Ghozali, 2016:47). The relationship model between variables is contained in the following regression formula:

$Y=\alpha+\beta 1 X 1+\beta 2 X 2+\beta 3 X 3+\beta 4 X 4+\beta 5 X 5+\beta 6 X 6+e$

Information

Y: Career selection to become an internal auditor; : Constant; : Regression coefficient;

X1: Financial rewards; X2: Professional training ; X3: Social values;

X4 : Work environment; X5: Labor market considerations;
X6: Personality; e : Error

\section{Results}

\section{Respondent's Descriptive}

The object of research used in this study were Accounting students at the University of Jember who took part in the Academic Awareness Program organized by IIA Indonesia for 3 months. The data collection method uses a saturated sampling method or a census in which all members of the population are used as samples. There are 105 samples, from the total number of questionnaires that have been distributed, namely 105 questionnaires, there are 105 questionnaires that were returned in their entirety. The duration of distributing the questionnaires in this study was for 3 weeks and 4 days starting from November 22 to December 17, 2019. Overview respondents present descriptive data that describes the condition or condition of the respondent which is additional information to understand the research results.
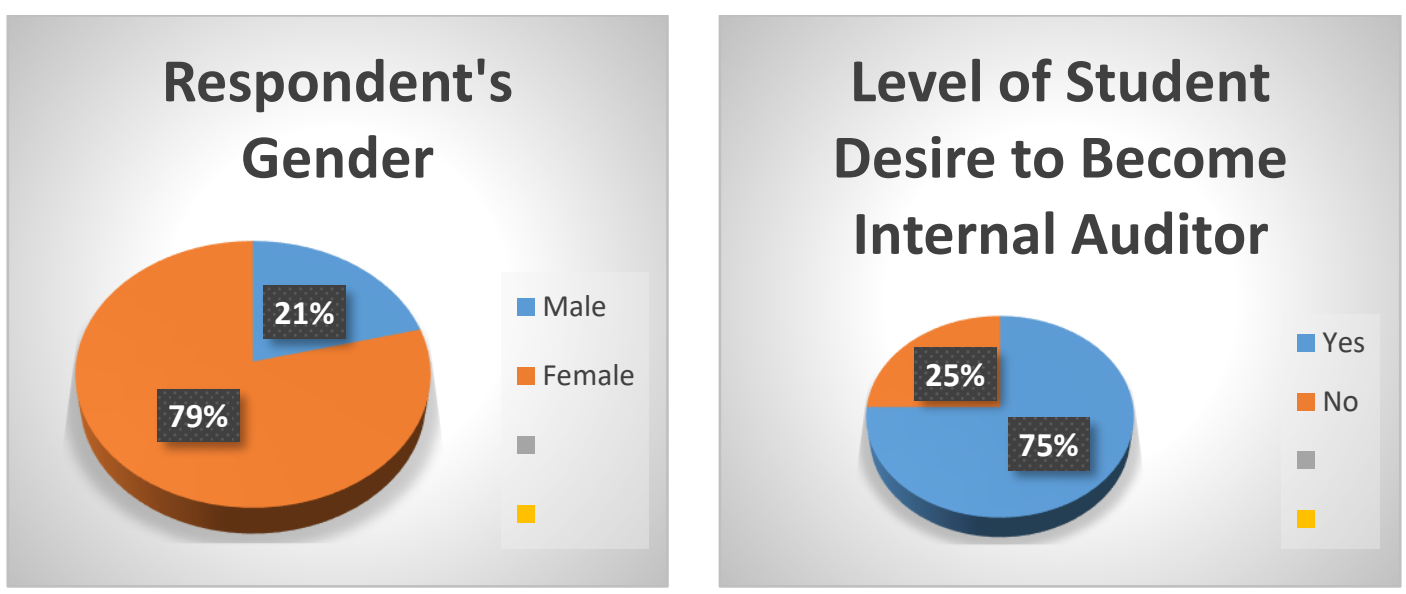

Figure 2: Respondent's Descriptive

Based on Figure 2, it can be seen that the number of female respondents was more than male respondents, namely 83 people $(79 \%)$, while male respondents were only 22 people $(21 \%)$. It can be seen that of the 105 respondents, the number of respondents who have plans for a career as internal auditors are 79 people $(75 \%)$, while the number of respondents who do not have plans for a career as internal auditors are 26 people
(25\%).

Table 2 below is the result of the validity test using the SPSS application. the test results show that all question items for variable measurement have a value of $\mathrm{Sig}<0.05$ and have Rcount > Rtable. It can be concluded that the variable statement item is declared valid. 


\section{GENERAL MANAGEMENT}

\begin{tabular}{|c|c|c|c|c|}
\hline variables & Items & Rtable & Rcount & Sig \\
\hline \multirow{5}{*}{$Y$} & Y.1 & 0,821 & 0,176 & 0,000 \\
\hline & $Y .2$ & 0,883 & 0,176 & 0,000 \\
\hline & $\overline{Y .3}$ & 0,814 & 0,176 & 0,000 \\
\hline & Y.4 & 0,621 & 0,176 & 0,000 \\
\hline & $Y .5$ & 0,722 & 0,176 & 0,000 \\
\hline \multirow{3}{*}{$\mathrm{X} 1$} & $\mathrm{X} 1.1$ & 0,897 & 0,176 & 0,000 \\
\hline & $\mathrm{X} 1.2$ & 0,941 & 0,176 & 0,000 \\
\hline & $X 1.3$ & 0,894 & 0,176 & 0,000 \\
\hline \multirow[t]{4}{*}{$\mathrm{X} 2$} & X2.4 & 0,840 & 0,176 & 0,000 \\
\hline & X2.5 & 0,932 & 0,176 & 0,000 \\
\hline & X2.6 & 0,881 & 0,176 & 0,000 \\
\hline & $\mathrm{X} 2.7$ & 0,896 & 0,176 & 0,000 \\
\hline \multirow[t]{4}{*}{ X3 } & X3.8 & 0,800 & 0,176 & 0,000 \\
\hline & X3.9 & 0,789 & 0,176 & 0,000 \\
\hline & X3.10 & 0,828 & 0,176 & 0,000 \\
\hline & X3.11 & 0,767 & 0,176 & 0,000 \\
\hline \multirow[t]{7}{*}{$\mathrm{X} 4$} & $X 4.12$ & 0,618 & 0,176 & 0,000 \\
\hline & X4.13 & 0,529 & 0,176 & 0,000 \\
\hline & X4.14 & 0,538 & 0,176 & 0,000 \\
\hline & $X 4.15$ & 0,338 & 0,176 & 0,000 \\
\hline & X4.16 & 0,497 & 0,176 & 0,000 \\
\hline & X4.17 & 0,706 & 0,176 & 0,000 \\
\hline & X4.18 & 0,678 & 0,176 & 0,000 \\
\hline \multirow[t]{5}{*}{$\mathrm{X} 5$} & X5.19 & 0,839 & 0,176 & 0,000 \\
\hline & $\times 5.20$ & 0,869 & 0,176 & 0,000 \\
\hline & X6.21 & 0,860 & 0,176 & 0,000 \\
\hline & $X 6.22$ & 0,809 & 0,176 & 0,000 \\
\hline & X6.23 & 0,696 & 0,176 & 0,000 \\
\hline
\end{tabular}

Table 2: Validity Test Results

Table 3 below is the result of the reliability test using the SPSS application. All variables in this study have a value greater than the reliability standard, which is 0.60 , it can be concluded that all of the variable questionnaire instruments in this study were declared reliable or reliable.

\begin{tabular}{|l|l|l|}
\hline Variables & $\begin{array}{l}\text { Cronbach's Alpha if Item } \\
\text { Deleted }\end{array}$ & Standart Reliability \\
\hline$(Y)$ & 0,801 & 0,60 \\
\hline$(X 1)$ & 0,840 & 0,60 \\
\hline$(X 2)$ & 0,812 & 0,60 \\
\hline$(X 3)$ & 0,811 & 0,60 \\
\hline$(X 4)$ & 0,840 & 0,60 \\
\hline$(X 5)$ & 0,833 & 0,60 \\
\hline$(X 6)$ & 0,825 & 0,60 \\
\hline
\end{tabular}

Table 3. Result of Reliability Test

Table 4 below is the results of multiple linear regression tests using SPSS analysis. From the table it is known that Professional Training (X2) and Personality are factors that influence the choice of career as an internal auditor $(Y)$. Other variables in this research model have no significant effect. 


\section{GENERAL MANAGEMENT}

\begin{tabular}{|l|l|l|l|}
\hline Variables & Regression Coefficient & Sig. & Note \\
\hline Constant & $-2,155$ & & \\
\hline (Y) & 0.200 & 0.050 & Not Significant \\
\hline (X1) & 0.315 & 0.002 & Significant \\
\hline (X2) & 0.016 & 0.886 & Not Significant \\
\hline (X3) & 0.152 & 0.071 & Not Significant \\
\hline (X4) & 0.110 & 0.575 & Not Significant \\
\hline (X5) & 0.789 & 0.000 & Significant \\
\hline
\end{tabular}

Table 4: Multiple Linear Regression Analysis Test

\section{Discussion}

\subsection{The Influence of Financial Awards on Career Selection to Become Internal Auditor}

Based on the results of the t test on the first hypothesis $(\mathrm{H} 1)$, it is concluded that the Financial Award does not have a significant effect on Career Selection to Become an Internal Auditor. Income or financial / salary rewards that are obtained as a counter-achievement from work are believed to be fundamental by most companies as the main attraction for providing satisfaction to their employees, rational financial compensation is a fundamental need for job satisfaction (Lestari, 2016). The results that have been obtained from this study indicate that the desire of accounting students participating in AAP Part 1 at the University of Jember to obtain financial awards is not a significant incentive for a career as an internal auditor. It may be due to the fact that students or respondents, who are mostly women, do not really think that financial rewards are a major factor, because based on their psychology, women tend to choose careers that suit their desires, while men tend to look for whatever the work has the highest income (Dilla, 2018). The financial rewards in this study were tested with 3 statement items regarding the things the respondents expected about high starting salaries, faster salary increases and the availability of pension funds. These things are not the main reasons for respondents to become an internal auditor. This research is in line with Eldiana (2018), which states that financial rewards have no significant effect on career choices as a public accountant. However, this study is not in line with Wulandari (2011) which states that financial rewards have a significant effect on career choices for accounting students.

\subsection{Effect of Professional Training on Career Selection to Become Internal Auditor}

Based on the results of the test on the second hypothesis $(\mathrm{H} 2)$, it is concluded the Financial Award has a significant effect on Career Selection to Become an Internal Auditor. Professional training includes matters related to recognition of achievement, a training program is an educational program carried out systematically and organized and is guided by professionals to improve skills in the field of work in order to achieve the work goals desired by the company or organization and improve and develop the attitudes, behavior, skills and knowledge of employees in accordance with the wishes of the company (Eldiana, 2018). The results of this study indicate that professional training is a major factor that can encourage students to become internal auditors. Students expect job training before work starts, training outside and inside the institution to increase professionalism and be able to get a variety of work experiences. Professional training is a provision and enhancement of skills provided by an organization for prospective employees and permanent employees, it can provide direct benefits for employees and prospective employees, therefore students are interested in becoming an internal auditor. This research is in line with resea Eldiana (2018), Daulay (2016), Wulandari (2011) which states that professional training is considered by students and has a significant effect on career choices for accounting students.

\subsection{The Influence of Social Values on Career Selection to Become Internal Auditor}

Based on the results of the test on the third hypothesis $(\mathrm{H} 3)$, it is concluded Social Values do not have a significant effect on Career Selection to Become an Internal Auditor. Daulay (2016) says that social values are related to people's views of the social values of a chosen career, care and attention from around an accountant will increase the intrinsic value and selling value of the accountant. Social values that are shown as factors that reveal a person's ability in society, or in other words, a person's value from the point of view of other people in his environment, from the results of his research shows that social values are considered in choosing a profession. The results of this study indicate that social values are not the main factor that can influence students in choosing their careers. Accounting students at the University of Jember think that being an internal auditor cannot provide opportunities for them to carry out socia activities, interact with other people, cannot give them time to carry out hobbies and pay attention to other individual behavior. So that for students, being an internal auditor does not give them freedom and free time. Therefore, social values do not have a major influence on their decision to choose a career as an internal auditor. This research is not in line with Daulay (2016) and Wulandari (2011) which state that social values have a significant influence and are considered by accounting students in their career choices.

\subsection{Effect of Work Environment on Career Selection to Become Internal Auditor}

Based on the results of the $t$ test on the fourth hypothesis $(\mathrm{H} 4)$, it is concluded the Work Environment has no significant effect on Career Selection to Become an Internal Auditor. Daulay (2016) says that the work environment is everything that is around the workers and can affect them in carrying out assigned tasks. It is an atmosphere that includes the nature of work, the level of competition between employees and work pressure. The results of this study indicate that the work environment is not a major factor that can influence students in choosing their careers. Students who do not have work experience will not care about how their work environment is and the risks they will face at work because the most important goal after graduating from college is to get a job, earn enough income and have the position they want in a career, so that For students who want to become internal auditors, the work environment is not the main factor that can influence them in choosing a career. This research is in line with Eldina (2018) which shows that work environment factors do not have a significant effect and are not a consideration for accounting 
students in choosing their careers. However, this study is not in line with Daulay (2016) and Wulandari (2011) which states that the work environment has a significant effect on the career choice of accounting students.

\subsection{The Effect of Job Market Considerations on Career Selection to Become Internal Auditor}

Based on the results of the t test on the fifth hypothesis $(\mathrm{H} 5)$, it is concluded that the Labor Market Considerations have no significant effect on Career Selection to Become an Internal Auditor. Lestari (2016) said that the labor market considerations include, opportunities for development, ease of getting a job, job security are factors where the chosen career can last for a long time. Labor market considerations are closely related to jobs that can be accessed in the future. Jobs that have a broader job market will be more desirable than jobs with a small job market. The results of this study indicate that for accounting students at the University of Jember, a job that is easily accessible or known is not a major factor in determining their career, because to become an internal auditor one must have sufficient experience and a high level of professionalism, so that only few companies open vacancies for internal auditors because usually companies will recruit people who have worked for a long time or permanent employees who are in the company. Guaranteed job security is not a fundamental reason for students to become internal auditors, because students who will choose their careers do not really think about the risks they will face while working, so that for them there are still not many considerations of the labor market as internal auditors in Indonesia and it is not a factor that can influence accounting students to become internal auditors. This research is in line with Eldiana (2018) which shows that labor market considerations do not have a significant effect and are not a material for accounting students to consider in choosing their careers. However, this study is not in line with Daulay (2016) and Wulandari (2011) which states that labor market considerations have a significant effect on career choices for accounting students.

\subsection{The Influence of Personality on Career Selection to Become Internal Auditor}

Based on the results of the t test on the sixth hypothesis $(\mathrm{H} 6)$, it is concluded that personality has a significant effect on Career Selection to be an Internal Auditor. Personality is one of the potential determinants of individual behavior when dealing with certain situations / conditions (Yanti, 2014). Personality means the psychological characteristics from within that determine and reflect how a person responds to his environment. The results of this study prove that accounting students at the University of Jember choose a career as an internal auditor because the profession is in accordance with their personalities and skills and they have the motivation and interest to become a professional internal auditor. Accounting students assume that if they choose a job according to their personalities and skills, then it will be easier for them and they will be more enjoyable in carrying out their work later. Therefore, if students have such assumption, motivation and interest will emerge within themselves which will encourage them to choose a career as an internal auditor. This research is not in line with Eldiana (2018) which shows that personality does not have a significant effect and is not a factor that accounting students will consider in choosing their career.

\section{Conclusion}

Of the variables that are thought to have an influence on career choice as an internal auditor, it turns out that only two variables have been shown to have a significant influence, namely professional training and personality. The results of this study are very interesting, especially in capturing the phenomenon of the possibility of a change in orientation from the current generation in determining their career. This is a limitation that exists in this study, namely that it does not reveal career choice preferences based on the type of generation of job applicants. As revealed in many previous studies, that each generation has different characteristics. This condition may affect their career choice as well. Therefore research will be able to further explore this. This research has implications for policy makers, especially companies providing job vacancies as internal accountants to pay attention to the factors that are considered by applicants to fill these positions. By promising a number of facilities as desired by job applicants, it is hoped that the number of internal auditors will increase and the myths and stereotypes about this job will decrease or even become a positive sentiment.

\section{References}

[1] Afaq Ahmed, K., Sharif, N., \& Ahmad, N. (2017). Factors Influencing Students' Career Choices: Empirical Evidence from Business Students. Journal of Southeast Asian Research, 115. doi: $10.5171 / 2017.718849$

[2] Ahmed, K. Et Al. (1996) Factors Affecting Career Choice, Chartered Accountants Journal Of New Zealand, 75(3), Pp. 65-66.

[3] Bartlett, G. D., Kremin, J., Saunders, K. K., \& Wood, D. A (2016). Factors Influencing Recruitment of Non-Accounting Business Professionals into Internal Auditing. Behavioral Research in Accounting, 29(1), 119-130. doi:10.2308/bria51643

[4] Burton, F. G., Starliper, M. W., Summers, S. L., \& Wood, D. A. (2014). The Effects of Using the Internal Audit Function as a Management Training Ground or as a Consulting Services Provider in Enhancing the Recruitment of Internal Auditors. Accounting Horizons, 29(1), 115-140. doi:10.2308/acch50925

[5] Butler, S. A. Et Al. (2000) Student And Recruiter Insight On The Importance Of Job Attributes, Journal Of Managerial Issue, XII(3), Pp. 337-351.

[6] Chambers, R. (2012). Five Classic Myths About Internal Auditing. Retrieved From Https://laonline.Theiia.Org/FiveClassic-Myths- About-Internal-Auditing

[7] Daulay, M. 2016. Faktor-Faktor Yang Mempengaruhi Pemilihan Karir Mahasiswa Akuntansi Sebagai Akuntan Publik (Studi Kasus Pada Mahasiswa Akuntansi Universitas Muhammadiyah Sumatera Utara). Jurnal Fakultas Ekonomi Dan Bisnis Islam.

[8] Dippa, F. A. T., Mendra, N. P. Y., \& Bhegawati, D. A. S. (2020), Faktor-Faktor Yang Mempengaruhi Menjadi Akuntan Publik ( Studi Kasus Pada Universitas Mahasaraswati Denpasar). Jurnal Kharisma, 2, 262-283.

[9] Eldiana, I. R. 2018. Analisis Faktor-Faktor Yang Mempengaruhi Mahasiswa Akuntansi Dalam Pemilihan Karir Sebagai Akuntan Publik (Studi Empiris Pada Mahasiswa Akuntansi Fakultas Ekonomi Universitas Islam Indonesia). Jurnal Akuntansi.

[10] Ernst \& Young. (2007). Global Internal Audit Survey: A Current State Analysis With Insights Into Future Trends And Leading Practices. Retrieved From Http://Www.Juhtimine.Ee/Static/Artiklid/188.Globa L Internal 


\section{GENERAL MANAGEMENT}

Audit Survey.Pdf

[11] Filipczak, B. (1997) New Grads Want Balance, Training, 34(8), Pp. 10-12.

[12] Holland, J. L. (1959). A theory of vocational choice. Journal of Counseling Psychology, 6(1), 35-45. doi:10.1037/h0040767

[13] Holland, J. L., \& Gottfredson, G. D. (1992). Studies Of The Hexagonal Model: An Evaluation (Or, The Perils Of Stalking The Perfect Hexagon). Journal Of Vocational Behavior, 40(2), 158-170. Https://Doi.Org/10.1016/0001-8791(92)90063-6

[14] Kerka, S. (2000). 'Career Choice, Gender, Race And Class'. Eric Cleaning House On Adult Career And Vocational Education Columbus. ED 421641

[15] Lestari, L. P. 2016. Relevansi Pemahaman Mahasiswa Akuntansi Terhadap Faktor- Faktor Yang Melatarbelakangi Keputusan Pemilihan Karir Akuntan Publik Dan Non Akuntan Publik (Studi Empiris Pada Mahasiswa Akuntansi UNDIP Dan UNPAND). Jurnal Universitas Pandanaran Semarang.

[16] Lestari, L. Puji. (2011). Relevansi Pemahaman Mahasiswa Akuntansi Terhadap Faktor-Faktor Yang Melatarbelakangi Keputusan Pemilihan Karir Akuntan Publik Dan Non Akuntan Publik. Jurnal Ilmu Ekonomi Aset, 13(1), 126.

[17] Messier, W. F., Reynolds, J. K., Simon, C. A., \& Wood, D. A. (2011). The Effect Of Using The Internal Audit Function As A Management Training Ground On The External Auditor's Reliance Decision. Accounting Review, 86(6), 2131-2154. Https://Doi.Org/10.2308/Accr-10136

[18] Murphy, M. (2013). Internal Audit Staffs Need To Foresee Talent Shortages: Ceb. Retrieved From Http://Blogs.Wsj.Com/Cfo/2013/01/17/Internalaudit- StaffsNeed-To-Foresee-Talent-Shortagesceb/

[19] Navallas, B., del Campo, C., \& Camacho-Miñano, M.-M. (2017). Exploring auditors' stereotypes: the perspective of undergraduate students. Revista de Contabilidad, 20(1), 2535. doi:10.1016/j.rcsar.2015.11.001
[20] Nouri, H., Parker, R. J., \& Sumanta, S. (2005). Students Perceptions Of Work In Public Accounting And Employment Preferences. Accounting Education, 14(3), 293-311. Https://Doi.Org/10.1080/06939280500077236

[21] Pekkaya, M. (2015). Career Preference of University Students: An Application of MCDM Methods. Procedia Economics and Finance, 23, 249-255. doi:10.1016/s2212-5671(15)00486-4

[22] Pricewaterhousecoopers. (2006). Pricewaterhouse Coopers 2006 State Of The Internal Audit Profession Study Shows That Continuous Auditing And Monitoring Is Today's Growing Business Trend. Retrieved From Https://Globenewswire.Com Newsrelease/2006/06/26/345020/101260/En/Pri

Cewaterhousecoopers-2006-State-Of-The-Internal- AuditProfession-Study-Shows-That-Continuous- Auditing-AndMonitoring-Is-Today-S-Growing- Business-Trend. Html

[23] Super, D. E. (1980). A life-span, life-space approach to career development. Journal of Vocational Behavior, 16(3), 282-298. doi:10.1016/0001-8791(80)90056-1

[24] Timporok, A. J., Sondakh, J. J., Gerungai, N. Y. T., Yang, A F., \& Mahasiswa, M. (2019). Analisis Faktor-Faktor Yang Mempengaruhi Mahasiswa Akuntansi Terhadap Pemilihan Karir Sebagai Akuntan Publik Pada Mahasiswa Akuntansi Universitas Sam Ratulangi Manado. Jurnal EMBA: Jurnal Riset Ekonomi, Manajemen, Bisnis Dan Akuntansi, 7(4). Https://Doi.Org/10.35794/Emba.V7i4.25441

[25] Vroom, V. (1964). Expectancy Theory - Victor Vroom; 1964 ( Process Theory ) Expectancy Theory - Victor Vroom; 1964 ( Process Theory ). 1964, 1-2.

[26] Walker, T. L. (2016). The Role Of Future Time Perspective In Career Decision Making Autor ( Es ): Publicado Por: URL Persistente: DOI : Accessed: Walker, Terrance L .; Tracey , Terence J . G .

[27] Wood, D. J., \& Wilson, J. A. (1989). Roles And Relationships In Internal Auditing. Altamonte Springs, FL: The Institute Of Internal Auditors Research Foundation. 